in Europe, received at these stations, will be graphically represented on maps, and these maps will be exhibited between four and five P.M. at a central point of the town, under glass, for public use. Besides there will be given a prognostic of weather for the following day; and this information will be sent to each commune and person who will pay monthly the sum of I 5 francs. This system is already introduced in Zurich and Berne, and the prognostics are correct in eight cases out of ten.

WE have received from Mr. Downing, of Whiskin Street, a neat little cabinet of twenty specimens of rocks, fossils, and minerals to illustrate Geikie's Geology Primer. Considering the number and quality of the specimens, and their suitability for the purpose, the cabinet is a wonder of cheapness, and ought to have a wide sale.

IN view of the apparently insurmountable dificulties which attend the completion of the New National Opera House on the Victoria Embankment, the Globe understands that all the agentsgeneral for the different colonies have entered into negotiations for the purpose of securing this site for the proposed Colonial Museum.

INTERESTING correspondence has appeared in the British Guiana Royal Gazette, we learn from the Colonies and India, relative to the qualities assigned to the fruit of the papau-tree. It has been recently asserted, in an article in the Pharmaceutical Fournal, "that the most interesting property attributed to it is the power of its juice to render bad flesli tender." Mr. Monro, of Georgetown, furnishes certain facts which he says are commonly known to the natives of British Guiana relative to this fruit. A horse tied near one of these trees rapidly loses health, and a stud horse becomes aseless. Any pressure on the body of the animal leaves an inelastic indentation. The sap of the tree will soften steel, and before the process of tempering was known in the Colony, the blacksmiths used to drive their brittle chisels and plane vices into the wood, leaving them there for a day c $r$ two; and tough meat wrapped in the leaf for only a few minutes becomes tender, and the same thing happens if it be suspended against the tree itself. The seed of the ripe fruit is an excellent vermifuge, and children have a great partiality for it.

In a recent paper in the fournal de Physique complementary of the theory of dew, M. Jamin points out that moist surfaces are subject to two superposed causes of cooling, one radiation (like dry substances), the other evaporation. The difference between the two actions is that the former persists at every tem. perature, while the latter, at first considerable, decreases and becomes $n i l$ when saturation is reached (it does not produce dew, but contributes to prepare and accelerate it, for it renders the air both moister and colder). The quantity of heat borrowed from the air by evaporation is very considerable : I gramme of evaporated water lowers about one degree the temperature of 2,553 grammes of air (or nearly two square metres' volume). Thus is explained how moist bodies, like plants, especially herbaceous, are cooled much more quickly than dry bodies. The dew forms on them more quickly; once it has commenced it continues by the sole effect of radiation. In driving rapidly down from a plateau into a valley one is often struck with the sudden cold. This culd is probably the effect of more rapid evaporation from the herbs, aquatic plants, and all moist surfaces of the valley. Other facts illustrate the double effect of radia. tion and evaporation, e.g., the danger of plants in early spring after being moistened by a shower, and the well-known mode of manufacture of ice in Bengal. The rôle of dew is that of moderating and sometimes arresting the nocturnal cooling, and preserving plants from the early frost.

AN interesting lecture on certain enigmatical phenomena of astronomy has been recently delivered by $M$. Houzeau before the Belgian Academy of Sciences, of which he is president. The points he takes up are, the apparent enlargement of heavenly bodies near the horizon (not adequately explained by a weakening of the rays, or interposition of terrestrial objects) ; the supposed satellite of Venus, observed seven times in 119 years, by eminent astronomers, but quite unobserved during the $\mathrm{r}_{4}$ years since; the phenomena connected with Biela's comet; the effects of the earth encountering a comet (may such a thing occur? has it occurred?); and the zodiacal light. The lecture appears in the Academy's Bulletin (No. 12 of 1878 ).

WE have on our table the following books:-_t Text-Book of the Steam Engine," T. M. Goodeve (Crosby, Lockwood, and Co.); "The Aborigines of Victoria," 2 vols., R. Brough Smith (Trubner); "Report of the British Association for the Advancement of Science, 1878," Dublin (Murray); "The Circle and Straight Line," John Harris (Wertheimer, Lea, and Co.); "Moore's Columbarium," reprinted by W. B. Tegetmeier (Field Office); "Practical Treatise on the Manufacture of Sulphuric Acid," A. G, and C. G. Lock (Sampson Low and Co.); "Atlas of Histology," Part i., E. Klein and E. N. Smith (Smith, Elder, and Co.); "Geologische Uebersichtskarte des Tirolisch-Venetianischen Hochlandes zwischen Etsch und Piave," 6 Maps, Dr. Edmund Mojsisovics, (Vienna: A. Holden); "Die!Dolomit-Riffe, ron Sudtirol und Venetien," Heft i. to vi., E. V. Mojsisovics (Vienna: Alf. Holden); "Meteorological Observations made at the Adelaide Observa. tory, years 1876 and 1877 ," Ch. Todd; "Journey through Khorassan," 2 vols, Col. C. M. M'Gregor (Allen and Co.); "Lakes and Mountains of Africa," I. F. Elton (Murray); "On the Annelida Chrotopoda of the Virginian Coast," H. E. Webster; "Fécondation des Fleurs," E. and G. Gevaert (G. Mayolez).

Trzadditions to the Zoological Society's Gardens during the past week include three Japanese Deer (Certnis sika) from Japan, presented by the Viscount Powerscourt, F.Z.S. ; a Syrian Bear (Ursus syriacus) from West Asia, prèsented by Dr. J. Huntley; a Green Monkey (Cercopithecus callitrichus) from West Africa, presented by Miss E. A. B. Payton; a Pig-tailed Monkey (Macacus nemestrinus) from Java, presented by Mrs. J. E. Fenton; a Coati (Nasua rasica), an Acouchy (Dasyprocta acouchy) from British Guiana, two Mountain Finches (Fringilla montifrimgilla), British Isles, purchased.

\section{SCIENCE IN RUSSIA}

$W^{E}$ take from the just issued Annual Report of the St. Petersburg Academy of Sciences for $\mathrm{x} 878$, the following information as to the work done by the Academy during the year in the mathematical and physical sciences.

Prof. Chebysheff has continued his researches inio the properties of parallelograms which consist of three elements, and are symmetrical with respect to one axis, these researches already having led him to important results; among them we notice his general formula for determining what are the simplest combined systems which, when set in motion, give a straight line.

Prof. Minding has published two papers, one of which is an important addition to his former researches on curves.

The Pulkova Observatory has published the ninth volume of its Memoirs, which contains the micrometrical measurements of double stars by Prof. O. Struve, during forty consecutive years. The value of these very numerous and precise measurements is much increased by the circumstance that they were made during so long a period by the same person, with the same instruments, and on the same methods; the comparison of M. Struve's observa tions with those of several known astronomers affords a means of reducing all of them to one system.

The transit of Mercury was observed at Pulkova with fourteen telescopes. It is worthy of notice that the observations proved that Mercury does not have such a dense atmosphere as that discovered around Venus.

The interesting researches of the late Prof: Asten into the 
motion of the comet of Encke were already well prized by all men of science. The Memoirs of the Academy contain this year a new work by Prof. Asten, on all the appearances of that comet from 1819 to 1875 . M. Asten has published also new ephemerides of the comet for this year, and their precision was already proved by the numerous observations made in the southern hemisphere. Unhappily he could not see this brilliant confirmation of his researches, death having taken him from the ranks of men of science.

Prof. Bredikhine was engaged in very interesting researches into the tails of comets, and he established that there are three quite different kinds of tails, according to the different relations between the attractive and the dispersive force of the $s$ un, which last is modified by the different properties of the particles of which the tail is formed. Spectral analysis will probably confirm this hypothesis,

As to spectral analysis in its application to heavenly bodies, the report states that it is not based, as yet, on sufficiently positive data, and that to elaborate these data with the accuracy usual to other astronomical observations, is the special aim of the astro-physical department of the Pulkova Observatory. Thus M. Hasselberg has published two works, one of which reduces the observations of Kirchhoff to wave-lengths, and the other deals with a precise description of the spectra of absorption of $\mathrm{NO}_{2}$, and bromine. The same author has recently proved that the displacement of spectral lines does not depend upon the density of the gas.

Observations on the variations of luminosity of stars were pursued by $M$. Lindemann, who has added 42 other stars to the 280 variable stars, included in the catalogue of $M$. Sjölerup. Prof. Savitch has made observations on oppositions of planets and on the transit of Mercury. He has also read at the Academy a paper on corrections on the pendulum of Repsold. Finally, we notice the observations of $M$. Njuren on earthquakes, as noticed by vibration of the sensitive levels of astronomical instruments,

In physical science the report begins with the work of the Central Physical Observatory at St. Petersburg. The Director of the Observatory, Prof. Wild, has a memoir on the determination of the real temperature of the air by a thermometer, and on the precautions to be taken for avoiding various secondary influences on the instrument, especially those of radiation. Thermometers which allow the determination of the temperature of the air with a precision of one-tenth of degree, have already been introduced into Russian meteorological stations. Besides, Prof. Wild has proposed very satisfactory improvements in the siphon barometer which allow easily the transportation of the barometer dismounted, without changing its error, and thus afford a means for nmparing with great accuracy the normal barometers of different stations. After having given, during the preceding years, special attention to terrestrial magnetism, the Central Physical Observatory has occupied itself with atmospheric pressure, and Capt. Rykatcheff has published a paper on the diurnal changes of barometrical pressure, based on the observations of eleven Russian and twenty-four foreign stations. The theory for explaining the diurnal changes of pressure, proposed by $M$. Rykatcheff, seems to be more probable than that of Dove, usually accepted until now. Among other meteorological papers, published by the Academy, there are worthy of notice those by Prof. Lenz, on the Galvanic Resistance of Solutions of Salts of Kalium, Natrium, and Ammonium; by Capt. Rykatcheff, on Winds on the Baltic; by M. Dorandt, on Anemometers ; by M. Hellmann, on the Comparison of the Normal Barometers at St. Petersburg, Helsingfors, Dorpat, Stockholm, and Upsala ; and by M. Stelling, on the Intensity of Day-Light at St. Petersburg.

In chemistry Prof. Menshutkin has continued his researches on the Influence of the Isomerism of Alcohols and Acids on the Formation of Compound Ethers ; and the Report notices among the chemical papers which have appeared in the publications of the Academy, those by Mrs. Lermantoff, on the Influence of the Tertiary Sodic Butyl on Isobutylene, and by M. Paoloff and Jawein, on Organic Chemistry.

In geology the year 1878 is marked by the appearance of the most important work, by Prof. Frederick Schmidt, on Silurian Trilobites of the Eastern Coasts of the Baltic, being the result of twenty years' researches, and of a thorough comparison of Russian trilobites with those of other countries. The work will contain the description of about 140 species; the first fascicule, actually in the press, contains a general description of the silurian rocks in the governments of St. Petersburg and Esthonia. Prof. Meller has described the collections brought from the Manyeh by M. Danilcosky, and has proved the former extension of the Caspian very near to the Sea of Azov.

In botany the first place is occupied by the work on the Algx of the White Sea, by M. Gobi. Prof. Famintzin has continued his researches into the embryology of plants, and by means of preparations made on the method of Nestermeyer, he has arrived at important results as to the formation of tissues in the embryons of plants. M. Klinge has made very interesting histological researches on roots of several Monocotyledons.

In zoology Prof. Brandt has published important additions to his former work (appeared in 1877) on the Rhinoceroses, living and extinct. But the most interesting of his works is certainly that on the Elasmotherium. Judging by the few teeth, found until now, of this extinct mammal, which formerly inhabited Europe from the Rhine to the Kirghiz Steppes, lrof. Brandt had described the elasmotberium as a form of the family of rhinoceros, but very near akin to the horse. A complete skull of this animal, which was recently found at Sarepta, on the Volga has quite confirmed the opinions of this zoologist. The elasmotherium is most nearly related to several kinds of rhinoceros, having at the same time several features common with the horse, and forms a separate sub-family of rhinoceros; he lived at the same time as the bison, the rhinoceros, tichorhinus and man. Prof. Kessler gives interesting descriptions of new fishes from Central Asia. M. Mereshkofsky has explored the sponges of the White Sea, and M. Boetger is publishing an important monograph on the Clausilia. Finally, the Report mentions the works of Prof. Ovsiannikoff on the anatomical structure of the cerebrum of the dolphin and other vertebrata, and the papers by Prof. Gruber, on variations of the muscles and the bones of man.

In the report of the historico-philological section of the Academy we mention the works of Prof. Dorn on inscriptions in the Pelegvian language and on the Semnan language, a now nearly extinct branch of the Iran branch; and memoirs, by Prof. Schiffner, on Buddhism; and by Prof. Wideman, on Finnish languages, namely, of that of Zyryans.

As to the premiums awarded by the Academy, those bearing Lomonosoff's name, for works in chemistry, physics, and mineralogy, and Buniakofsky's, for works in mathematics, were not awarded this year. A new premium, bearing the name of $\mathrm{Hel}$ mersen, was founded this year for works in geology.

\section{UNIVERSTTY AND EDUCATIONAL INTELLIGENCE}

Prof. James Stuart's efforts to develop a school of Applied Science at Cambridge, have produced further fruit in the shape of a report of the Board of Mathematical Studies, recommending an alteration in the scheme of examination in mechanism and applied science for the ordinary B.A. degree. It is proposed now that papers on mechanics and on heat shall be obligatory on all candidates, while they shall choose one only of three other subjects, viz., (I) Mechanism. (2) Theory of Structure, Strength of Materials, and Principles of Surveying and Levelling. (3) Electricity and Magnetism. The examination is to be made as far as possible a satisfactory basis for a professional career by its practical character. Thus every candidate will be required to show his ability to write an accurate description or specification of an instrument, machine, or model exhibited, and to make a working sketch to scale. Evidence of actual capacity to use the tools or instruments belonging to the subject selected by the candidate will be demanded. The first class in the class list is to consist only of those who have distinguished themselves in one of the three alternative subjects. We do not doubt that it will soon be realized that a student who has to pass an examination in Greek and Latin in his second year will not have time to master his and Latin in his second year will not have time to master much Science subjects by the end of the third. There will be much bridge if they are excused from the classical portions of the "General" Examination for the ordinary degree.

In the new scheme for the Classical Tripos at Cambridge, the advanced portion will include several groups of subjects, of which one only is to be selected by a candidate. Three of these groups are History, Archrology, and Language, and the knowledge and treatment required will be thoroughly scientific in character. Archæology will include papers on Greek and Roman 